\title{
The renouncement of possessions according to Matthew 19:16-30
}

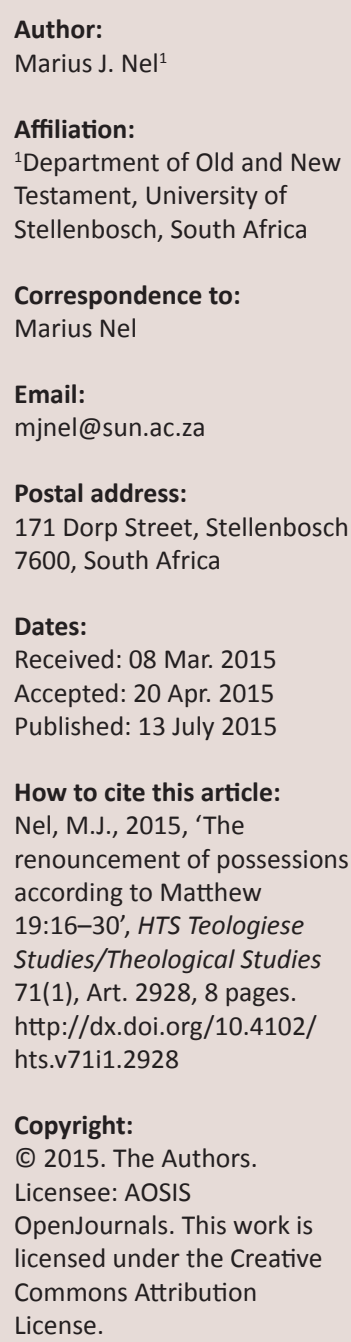

This article focuses on the renouncement of possessions in Matthew 19:16-30 in terms of three related questions. Firstly, it asks if the renouncement of possessions was, according to Matthew, a general requirement for following Jesus or for membership of the Matthean community. Secondly, it investigates if this requirement did not lead to a distinction within the Matthean community between those who adhered to a stricter ethic of Jesus and those who did not (i.e. between religious virtuosi and non-virtuosi)? Finally it enquiries as to what would have compelled followers of Jesus or members of the latter Matthean community to comply with it? The article concludes that at least some of the followers of Jesus are depicted by Matthew as having renounced their possessions as a sign of their unconditional commitment to him. The Matthean community could thus have been a two-tiered community comprised of virtuosi who had renounced all their possessions, as was demanded of the rich young man, and those who had not. The renouncement of their possessions could have been part of their initiation into the Matthean community and have been motivated by the promise of an incomparable eschatological reward. It further appears that while not all who were considered to be followers of Jesus had surrendered their possessions, all would share in God's eschatological reward if they provided hospitality to those who did.

\section{Introduction}

This article focuses on the renouncement of possessions in the Gospel according to Matthew. Three related questions will be addressed. Firstly, was the renouncement of possessions a general requirement for both following Jesus and for membership of the later Matthean community? Secondly, did this requirement lead to a distinction between pre- and post-Easter followers of Jesus who adhered to a stricter ethic and those who did not (i.e. between religious virtuosi and non-virtuosi)? Finally, what compelled some of these followers of Jesus to comply with his command to renounce their possessions?

In order to address the above-mentioned questions the article will focus on the encounter between Jesus and the rich young man in Matthew 19:16-30 as the clearest example of a command from Jesus directed at a potential follower to renounce his or her possessions. ${ }^{1}$ Thereafter it will investigate if the disciples and the intended readers of the first Gospel are understood by Matthew as having renounced their possessions. Or was the intention of Jesus' command to the rich young man simply to remind the disciples, and the readers of Matthew, of the reality that it was not possible for them to save themselves since it was impossible to obey all of Jesus' commands? In order to answer these questions a brief overview of Matthew's depiction of the use of possessions will be given before the possible function of the renunciation of possessions within the Matthean community will be discussed. In the fourth section the manner in which Jesus' command to the rich young man to renounce his possessions is substantiated in 19:27-30 will be addressed, after which a number of concluding remarks will be made.

\section{The rich young man and Jesus (Mt 19:16-26)}

In Matthew 19:16 Jesus is approached in the area beyond the Jordan by a young man

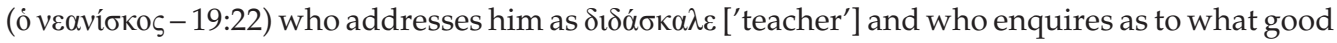
he should do in order to obtain eternal life. Jesus answers him by instructing him to keep the

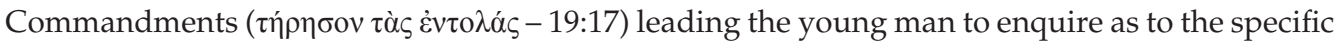
Commandment he should keep. Jesus replied by quoting a number of Commandments from the second tablet of the Decalogue, to which he added the Commandment to love one's neighbour found in Leviticus 19:18. On hearing Jesus' reply the young man affirmed that he had indeed

1.It should be noted that whilst Matthew 19:16-30 is primarily based on Mark 10:17-31 (there are, however, a number of smaller agreements with Luke), the focus of this article is on Matthew's depiction of the encounter between Jesus and the rich young man, and not on its complex textual tradition and reception. A number of remarks will be made where necessary in the footnotes on Matthew's redaction of Mark. 
kept them all, but that he feared that he was still lacking in

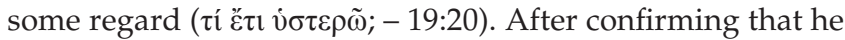
was indeed lacking one thing in order to be complete, Jesus

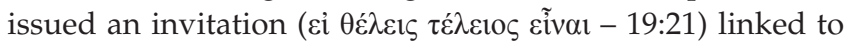
two imperatives to the young man. Even though the answer of Jesus is formulated as an invitation ('if you want'), it functions as a command (Luz 2001:513-514). If the young man wanted to be perfect in the sense of going beyond what is customary with regard to the Torah (cf. Matthew 5:20) he had to give up his possessions for the sake of the poor

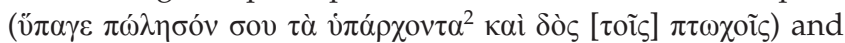
to commit himself completely to Jesus by following him

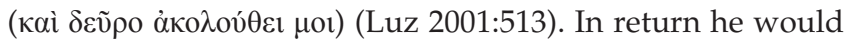

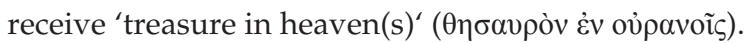

In response to Jesus' invitation the young man, according to Matthew, went away sorrowfully ( $\dot{\alpha} \pi \tilde{\eta} \lambda \theta \varepsilon v \lambda v \pi \circ \varepsilon_{\mu} \mu \varepsilon v \varsigma \varsigma$ ), for although he found the offer of Jesus attractive (hence his sorrow in not being able to comply), the cost involved

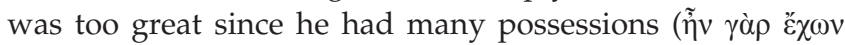
$\kappa \tau \eta \dot{\mu} \alpha \tau \alpha \pi \mathrm{o} \lambda \lambda \alpha \dot{\alpha})$. In reaction to the young man's departure, Jesus commented on the difficulty the rich had in entering the kingdom of heaven (19:22-24), leading the disciples to ask who could then be saved? To which Jesus replied that salvation was only possible for God (19:25-26).

\section{The renunciation of possessions in Matthew}

The demand of Jesus to the rich young man to sell his possessions and to give the proceeds of the sale to the poor (Mt 19:21) raises the question as to how possessions and their use are otherwise depicted in the Gospel according to Matthew. Was the renouncement of possessions a general command which the first followers of Jesus, and Matthew's intended readers, were all expected to adhere to? Or does the disciple's question about who could be saved

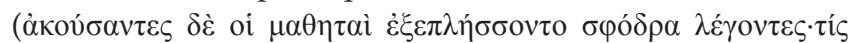

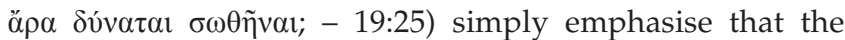
standard (the renouncement of all possessions) set by Jesus for obtaining perfection was impossible to meet in order to underline that only God could save? Was it in other words a pseudo command that was impossible to obey and which thus had no influence on the manner in which the Matthean community utilised their possessions? That its rhetorical function was solely to emphasise the authority of Jesus (he could demand total obedience from those who wanted to follow him)? If it was, however, intended to be a genuine requirement for being a follower of Jesus, the question arises as to its function and effect on the composition of the Matthean community. To answer these questions a brief overview of Matthew's depiction of the use of possessions will be given ('Possessions in Matthew') before the possible function of the renunciation of possessions will be discussed ('The function of the renouncement of possessions in Matthew').

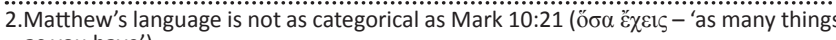
as you have').

\section{Possessions in Matthew}

In Matthew Jesus is depicted as both the recipient of the generous gifts of others (e.g. the expensive gifts of the Magi (2:11) and the precious ointment of a nameless women [26:7-12]) and as one who has the freedom to use the possessions of both followers and supporters as he sees fit. Animals (an ass and colt - 21:2), houses (9:10, 28; 13:1, 36; $17: 25 ; 26: 18)$, boats, food and even a burial cloth and a tomb (27:59-60) are all depicted as being at the disposal of the Matthean Jesus. Men and women, rich and poor, adults and children are depicted as acknowledgement of the authority of Jesus by putting their possessions at his disposal. It is only with the crucifixion that the ultimate rejection of Jesus is signified by him conversely being stripped of all his possessions (Mt 27:28-31). The giving, lending and taking of material possessions thus serve as important indicators of different character's acceptance, or rejection, of Jesus' authority in Matthew.

In line with the above-mentioned freedom of Jesus to use the possessions of others, Matthew depicts Jesus' command to the rich young man to sell his possessions as being in line with his teaching and ministry. It, for example, resonates with the warning of Jesus in Matthew 6:19-34 to not amass treasures on earth, but rather in heaven, which Matthew applies to all believers. The renouncement of property and family ties are, furthermore, evident in a number of instances in Matthew where individuals are described as choosing to follow Jesus. The brothers Peter and Andreas, as well as James and John, abandon their work and family (Mt 4:18-22). Matthew leaves his tollbooth, but apparently not his house (9:9-13), in order to follow Jesus. A teacher of the Torah and a nameless disciple are also instructed by Jesus to abandon their homes and family but Matthew does not explicitly state if they complied (8:19-22). Peter's response to the encounter between Jesus and the rich young man was, according to Matthew, however to remind Jesus that he and the disciples had indeed left everything ${ }^{3}$ and

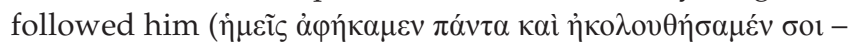
Mt 19:27). They had thus, according to his estimation, themselves done what the young man was being instructed to do. The Matthean Jesus in 19:29 also refers to 'all' (not only the twelve) who had left their family and possessions

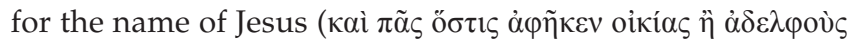

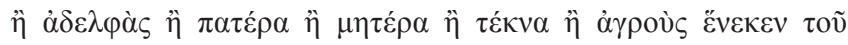

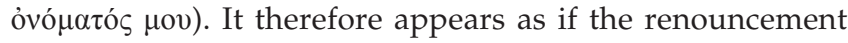
of possessions was practiced by at least some of Jesus' followers according to Matthew. The command to renounce all possessions was thus not a pseudo command for Matthew that simply emphasised that it was impossible to obey every command of Jesus and which therefore had no influence in the manner in which the Matthean community organised itself. The question therefore arises as to what would compel at least some followers of Jesus to renounce their possessions?

3.Matthew omits Mark's references to houses and lands which could indicate a more

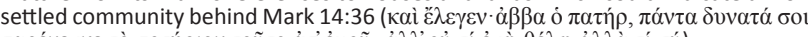

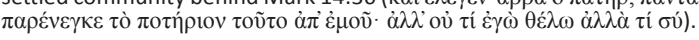




\section{The function of the renouncement of possessions in Matthew}

Although there could have been more than one reason why Matthew depicts the followers of Jesus as renouncing their possessions (e.g. possessions inhibit mobility or they might have raised funds for the community's ministry), the most likely is that it served as a sign of personal commitment to

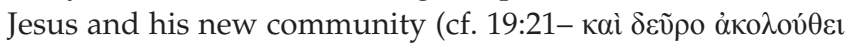
$\mu \circ 1){ }^{4}$ In this regard Klaus Berger (2003:244-246) notes that the giving up of possessions when converting to Judaism or Christianity is attested in the writings of both Hellenistic Judaism and the apocryphal Acts of the Apostles. ${ }^{5}$ A number of logia in Matthew also support the notion that one's attachment to possessions testifies to your commitment to God. According to Jesus, for example, no one can serve two masters (Mt 6:24). One, therefore, has to choose between serving God or Mammon. Renouncing your possessions could thus have been a radical way of concretising the choice not to succumb to the allure of possessions, but rather to obey the will of God as it was manifested in Jesus. It is more than a practical matter to improve the mobility or poverty relief funds of the followers of Jesus. It is rather the faithful response to Jesus' demand of unconditional allegiance to him. The renouncement of possessions therefore provides an important insight into the nature of the pre- and postEaster communities of Jesus followers reflected in Matthew since they are both described as being institutions that made absolute claims of their members.

The sociologist Lewis Coser (1974) has coined the term 'greedy institutions' in order to describe various organised groups that make absolute, unlimited claims on the limited energy and time commitments of their members. They differ from 'total institutions' which, according to Ervin Goffman (1961:4), use overt coercion and physical barriers such as locked doors and high walls to restrain their members (e.g. prisons, mental hospitals, homes for the aged, concentration camps, and boarding schools). By contrast greedy institutions use non-physical mechanisms in order to cultivate the voluntary compliance of their members. They maximise assent to their lifestyle by presenting themselves as being highly desirable to their participants (Coser 1974:6) so that in the end their members become so committed to them that they are unavailable for alternative lines of action. For this reason Coser describes their demands on a person as 'omnivorous'. Amongst the historical examples Coser (1974:4-5) provides are the demands of charismatic leaders of new religious communities such as Jesus' demand of his disciples that they should forsake their families and follow him.

Recently Baumgarten (2007:5) has used Coser's description of greedy institutions in order to classify Jewish sects. Of these,

\footnotetext{
4.Matthew explicitly states that the funds raised by the sale of the rich young man's possessions should be given away to the poor (19:21). It is thus not utilised by the group of Jesus followers themselves.

5.See Luz (2001:512) for a list of examples of the renouncement of possessions with regard to conversion in the Greco-Roman world.
}

sects that require a sexual, financial (property assigned to the sect) or biological (biological family replaced by sectarian family) sacrifice meet Coser's criteria. In his discussion of ancient Jewish sectarians, Baumgarten (1997:44, 47) also notes that their membership was to a large extent comprised of men who were part of the economic, social and educational elite who could afford the 'luxury' of the indulgence in the affairs of the spirit. These men were well positioned to either attempt to change their culture from a position of advantage, or to become fierce opponents of the establishment (Baumgarten 1997:48). It could thus be that while differing from the profile of the other disciples of Jesus in Matthew that the rich young man, who is described as having a zeal for the Torah and seeking 'eternal life', fits the general profile of some of the male elite in 1st century Galilee who sought to become religious virtuosi. ${ }^{6}$ For Baumgarten (1997:52), the claim by Josephus of having tried out several groups before making a final choice was furthermore typical ${ }^{7}$ and that sects were well aware of the fact that many who joined them would not necessarily remain members, but would move on to other groups. ${ }^{8}$ It was, therefore, imperative for them to identify and discourage those who would not become permanent members of their respective groups like the Qumran and Essene communities did.

The Qumran community and the Essenes had regulations according to which potential members were not accepted at the outset, but rather had to undergo a process of admission lasting several years. During this initiation process initiates were expected to renounce their possessions. The Essenes who renounced their property are referred to as 'the Many' (הרבים) or 'the Community' (היחך) (Hays 2010:46). Only after they had been scrutinised for a year by the 'Many', were novices allowed to partake in the egalitarian common meal of the community (1QS VI 16-17; cf. 1 QS VI 24-25; Philo, Prob. 86) after which the inspector of the community assessed and took into holding their possessions and earnings (Hays 2010:46). These were, however, not yet shared with the rest of the community (1QS VI 18-20), and although the novices would then gain access to the drink of the community (1QS VI 20-21) it was only at the end of their 3rd year that they became fully integrated into the community. Only with their final integration were the novices' possessions shared with the community (1QS VI 22). According to the 'Rule of the Community' it was not only their possessions, but also their earnings which were shared with the community. The intention of the communal living was apparently to free people from their day to day economic struggles as

6.Matthew 10:34-39, which speaks of the conflict between members of households, could be referring to young people who were breaking with their families to join different sects or parties.

7.Paul, for example was initially a Pharisee, while some of the disciples of Jesus were initially disciples of John, according to John 1:35-42.

8.One of the reasons for the phenomenon was that there was not much difference in their world view. They all, for example, made similar claims of zeal to the law and for the need to keep themselves apart from others.

9.While the relationship between the Dead Sea Scrolls (DSS) and the writings of Philo and Josephus on the Essenes is a fiercely debated one, there is a general (but not univocal) agreement that some of the DSS are Essene documents and that Qumran was an Essene community (Hays 2010:46). 
an allusion to Isaiah 58:6-7 (or in the Damascus Document CD-A XIII 9-10) attests (Hays 2010:47).

It could thus be in light of the example of the Qumran community that the renouncement of possessions by the followers of Jesus similarly led to a communal life rather than to a life of complete possessionlessness. It should, however, be noted that the rich young man was instructed to sell his possessions and to give the proceeds away. The proceeds of the sale were thus not utilised by the community of Jesus' followers. Unlike the documents of the Qumran community the Gospel according to Matthew also does not give a clear indication of the precise process by which one would have been accepted into it. It also does not testify to a community as organised and isolated as the one at Qumran. The command to sell everything and to follow Jesus could thus simply have been a test of the young man's willingness to accept the authority of Jesus and to permanently commit to him (he would have no other recourse if he had left his family and possessions behind), without it forming part of an elaborate initiation process for which there is little evidence. ${ }^{10}$

\section{The renouncement of possessions as general requirement}

Although Matthew refers to the disciples and others who had renounced their possessions and families (19:27-29), it is not clear if he claims that all the initial followers of Jesus, and the entire Matthean community, actually did permanently renounce their possessions. While Matthew presupposes a group of Jesus' initial followers who, like Jesus, had become homeless (8:20), travelled from town to town (10:5-15), suffered persecution (10:23) and were rejected in a number of locales (10:40-42), it appears as if at least some of them led a more settled life since they are instructed to be generous in almsgiving (6:2-4), willing to lend freely to those who ask (5:42), and to provide hospitality to others (10:11). It is also apparent that despite leaving their families and economic support in order to follow Jesus (4:21-22), prominent disciples of Jesus are not described as being permanently dispossessed. James and John, for example, continue to be defined in terms of their relationship to their parents (Mt 10:2; 20:20). Similarly, Peter retains a house and a family (Mt 8:14), despite claiming to have left all to follow Jesus (Mt 4:18-20; 19:27-30). Jesus, furthermore, addresses (Mt 19:3-20:28) four standard elements of everyday household management the relationship between husband and wife (Mt 19:3-12), children (Mt 19:13-15), wealth (Mt 19:16-30) and slaves (Mt 20:17-28) - which all characterise a settled community (Carter 1994:192).

Matthew also directly addresses at least some of his intended readers, who appear to be similarly settled (Mt 24:15-28), when he warns them that they could be on the roof of their houses, working in their fields or nursing their babies when they would have to flee to the mountains when the Abomination of Desolation appears in the temple. They are

10.There is no example in Matthew of the holding of all possessions in common as is for instance described by Luke in Acts 2:44-45 (Johnson 1981:21). thus depicted as being part of a group reluctant to leave their houses, fields or families even in a time of unprecedented crisis (Theissen 1978:18). They are clearly not described as a band of wandering charismatics ${ }^{11}$ with no family or property.

How should the discrepancy between those who claimed to have renounced their possessions, and those who apparently did not, be understood? One possible explanation, that has already been mentioned (cf. see above 'The function of the renouncement of possessions in Matthew'), was that the renouncement of possessions was part of the process of initiating potential disciples into the community of Jesus followers and that it was not intended to be a permanent way of life. Matthew 10:40-42, which refers to the provision of hospitality to wandering Christian prophets (or little ones), does not appear to suggest that they were only active during the ministry of Jesus, and that the Matthean community had developed from a movement comprised of settled and dispossessed groupings into a fully settled one. Both the settled and the dispossessed groupings are presented as interacting with each other. It could thus rather be that the Matthean community had a permanent two tier structure in that it was comprised of different groupings of Jesus followers. One of these groupings can be described as being religious virtuosi ${ }^{12}$ since they had renounced their possessions in order to follow Jesus in an uncompromising manner and another as non-virtuosi followers since they kept their possessions and property; it was the latter group that was responsible for supporting the virtuosi who had. The possibility that varied responses to the command of Jesus to his followers to renounce their possessions had resulted in a two tier Matthean community therefore needs to be considered (see below 'The Matthean community as a two tier community').

\section{The Matthean community as a two tier community}

In terms of Matthew's community being a possible two tier one, the Essene movement provides a possible analogy since, according to Josephus, it had a two tier social structure (Capper 2009:72) comprised of groups adhering to a strict ethos, renouncing both possessions and marriage (Bellum judaicum 2.8.2-12), and groups with a more temperate ethos, in which both marriage (Bellum judaicum 2.8.13) and personal possessions were tolerated. The more temperate Essenes lived scattered about in camps and cities (Bellum judaicum 2.8.4). There was apparently regular contact between the different groupings with those in cities expected to provide hospitality to travelling members. Importantly, both groups were considered to be part of one movement. It is thus a question if the Gospel according to Matthew contains references to

11.Draper (1995:187-202; 1998:542) has questioned the depiction of the disciples of Jesus as wandering charismatics in the light of Matthew 10:1-11:1 since it describes a purposeful strategy of Jesus for his disciples. They do not aimles describes a purposeful strategy of Jesus for his disciples. They do not aimlessly wander from one place to another, but are rather sent by Jesus to specific town o serve as his representatives. They are thus not called to radical itinerancy as Theissen (1978) claims. It is, however, to be noted that other than Mark, Matthew
does not mention their return. Their return is, however, implied.

12.For an overview of Weber's (1963:162-165) understanding of 'virtuoso religiosity' and for a discussion of the Matthean community as having a two-tier structure see Nel (2014:729-744). 
both virtuoso and non-virtuoso followers of Jesus. And if so, whether the rich young man could be described as an aspiring religious virtuoso. In order to answer these questions it is important to briefly clarify what is meant by a religious virtuoso and then to enquire if Matthew - specifically 19:16-29 - exhibits the traits common to it.

In her comparative sociological study of monasticism in Theravada Buddhism and medieval Catholicism, Virtuosity, charisma, and social order, Ilana Silber (1995:190-194) develops a typology of virtuoso religion based on the work started by Max Weber. According to her typology, virtuoso religion can be summarised as exhibiting five key characteristics (Capper 2009:63): (1) Virtuosi religion is a matter of individual choice, that (2) involves the seeking of perfection in (3) a disciplined, systematic fashion, through a defined rule or method that (4) implies a normative double standard since its rigour is not possible for all and therefore (5) it is in practice only achieved by a 'heroic' minority. ${ }^{13}$ If her fivefold typology is applied to the interaction between Jesus and the rich young man in Matthew 19:16-29, a case can be made that most of the elements which Silber describes as being typical of virtuoso religion are present therein.

According to Matthew, it was (1) the young man's personal choice to go further than the routine norms and expectations expressed by the Torah (2) since he sought to be perfect (Mt 19:20). In order to become perfect the young man had to be willing to break the social and psychological ties with his family (he had to follow Jesus and travel with his group) as well as with his possessions. Jesus reacted to the young man's statement that he wanted to lack nothing, by calling him to follow him. The reason for following Jesus is not stated by Matthew. Presumably it was to be (3) instructed in a disciplined, systematic fashion like the twelve disciples who had been called by Jesus. The response of the disciples emphasises that the standard set by Jesus for obtaining

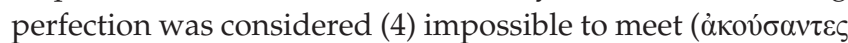

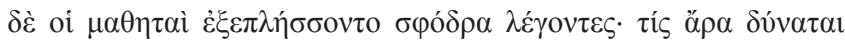
$\sigma \omega \theta \tilde{\eta} v \alpha l ;-19: 25)$. If it was a prerequisite for salvation the disciples conclude that only God could save them. The statement by Peter (Mt 19:27), however, suggests that while the commands of Jesus are stringent the disciples - a 'heroic' minority (5) in Silber's terms - did adhere to them. The response of the Matthean Jesus that not only the twelve disciples, but all who had left their families, property and lands would be rewarded (Mt 19:29) echoes similar references in Matthew to a select few (not only the disciples) who had met the demanding standards set for them (cf. Mt 7:13). It can thus be that some of them had become the religious virtuosi that the rich young man aspired to become.

That the young man sought out Jesus for instruction on how to live is in agreement with Matthew's depiction of Jesus as a teacher of a religious practice (i.e. virtuoso religion) that went further than the everyday religion of the masses. The

13.See Nel (2014:736-741) for an overview of Silber's characteristics and an application thereof to the Matthean community.
Matthean Jesus, for example, instructed his disciples to aspire to a righteousness greater than that of the experts of the law and the Pharisees (5:20), to seek to become perfect (5:48), and to live according to the intensified interpretation of the Torah taught by him (5:17-6:18). They are not to be caught up in everyday concerns (6:19-34), or to be satisfied with half-hearted religious practice. In contrast to those living according to the routine norms and expectations of Judaism, they were also not to live like the rulers of this world (20:25-28), or pray and give alms and practice their piety like the heathen or Jewish hypocrites (6:1-8, 15:1-20). They were rather to seek the higher righteousness of God (Mt 6:33). ${ }^{14}$ Matthew also presents the choice to follow Jesus, and to be part of his travelling group, consistently as a matter of personal choice through his description of the individual calling of two sets of brothers, a tax collector and a rich young man. The brothers are specifically described as leaving everything (4:18-22), and Matthew his tollbooth (9:9-13), in order to follow Jesus.

\section{The renouncement of possessions and the authority of Jesus}

The preceding overview of the role of possessions in Matthew points to the possibility that while the Matthean community included a settled group, who had not renounced their possessions, it also included a virtuoso group that had, and that was therefore dependant on the support of the settled group. In other words that both the settled and the dispossessed members of one community (or movement) had responded with different levels of commitment to the teaching of Jesus, but that both were considered to be authentic followers of Jesus. This possibility that followers of Jesus had responded differently to his commands and teaching raises questions about the nature and extent of his authority in Matthew.

While Jesus has been characterised as a charismatic leader by Hengel (1981:44) in terms of Matthew 19:16-30, this characterisation has been disputed by Bruce Malina (1996:123-142) since Jesus is at times depicted in the Gospels as having no real authority over others. Although he could command demons and nature to do his bidding, he is frequently disobeyed by people like the rich young man. Jesus also did not generate the impassionate loyalty to himself amongst his followers that characterises true charismatic leaders. In Matthew he is betrayed by Judas, denied by Peter and abandoned by his other disciples at his time of greatest need (Malina 1996:131). The refusal of the rich young man

\footnotetext{
14.The claim to articulate a virtuosi form of religion often leads to conflict with other groups within a society with similar claims. This could explain the conflict between the Matthean community and the Pharisees. It could thus be that Runesson (2008) is correct in identifying different layers of tradition in the Gospel according to Matthew that reflect different phases of the Matthean community's development. The reconstruction of the different phases and the identification of the different layers is, however, not an easy undertaking. Runesson understands the Matthean community to have been primarily comprised of Pharisees who believed in Christ and who were engaged in comprised of Pharisees who believed in Christ and who were engaged in process of internal conflict that eventually led to their gradual separation from the Pharisees so that Matthew's post-70 CE. stratum represents the Matthean community as a sect in relationship to the Pharisees (Runesson 2008:126-129), as is for instance suggested by the use of the pronoun 'your or their' in describing different synagogues (Mt 12.9, 13.54) according to Regev (2011:782). The flogging of Matthean members (Mt 10:17; 23:34) in non-Christian synagogues could, however, suggest that they continued to pray amongst Jews.
} 
to heed the commands of Jesus thus aligns with a number of instances in the Gospel according to Matthew that hints at limits to Jesus' authority. If authority is defined as 'the social recognition of the right to oblige others' (Malina 1996:123-142), the nature of Jesus' authority with regard to his demand that at least some of his followers renounce their possessions needs to be clarified.

From a sociological standpoint, groupings of people are usually led by elites that may be described from two perspectives. They could be those who de jure occupy the positions of highest authority within a social grouping or organisation, or they could represent a specific group's de facto authority by attaining its most respected values and with it the respect and loyalty of others (Capper 2009:62). In accordance with Matthew 19:16-30, Jesus can thus be described as having de facto authority since he exemplified what he expected of others even though he held no formal position or office within his society. Since Jesus had left his home and family, he could therefore command those who wanted to follow him to do the same. He could, however, not force them to comply. Thus the rich young man could decline Jesus' invitation to be his disciple and willingly disobey his command to sell his possessions. The encounter between Jesus and the rich young man is, however, paradoxical in nature since his refusal enhanced Jesus' reputation as a religious leader who had the authority to give commands that were difficult to obey. Conversely, the fact that Peter (Mt 19:27) and the other disciples had complied with Jesus' call to follow him, enhanced the status of those who did what others would not.

\section{The motivation for the renouncement of possessions}

It has been argued in this article that Matthew accepted that at least some pre- and post-Easter Jesus followers had obeyed Jesus' command to renounce their possessions (which gave their respective groupings the characteristics of Coser's 'greedy' institutions). The final question that therefore needs to be investigated is why they did so when Jesus only had de facto authority within his society?

In Matthew those who accept the authority of Jesus are described as being richly rewarded by him for doing so. In 19:28 Jesus promised the twelve disciples that in the remade

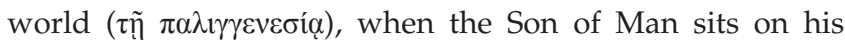
throne (cf. Ps 110; Dn 7:13), they would sit on twelve thrones judging the twelve tribes of Israel. The twelve are thus promised an exaltation that is out of all proportion to their present sacrifice (Luz 2001:517), as they would participate in the judgement by the Son of Man. This promise draws on the idea that the righteous ${ }^{15}$ would partake in the final judgement that occurs in Jewish texts like The Wisdom of Solomon 3:8 and 1 Enoch 38.5, 91:12; 95:3. It is, however, not only the twelve disciples who would be rewarded by God according to Matthew. Everyone who had left their houses,

15.Or the entire nation of Israel (Jub 24:29; 1 Enoch 90:19). families or property would receive a hundredfold reward

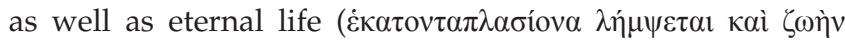

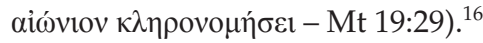

The language Matthew uses as motivation for obeying Jesus is consistently eschatological in nature. Matthew, for instance, has removed the distinction in Mark 10:30 between

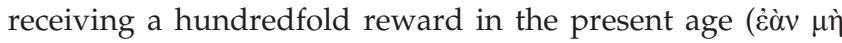

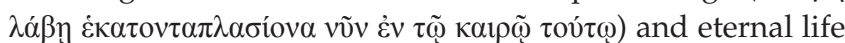
in the coming. Both rewards, according to Matthew 19:29 will only be received in the coming age. Matthew also does not use the plight of the poor ${ }^{17}$ in the present as a motivation for complying with the command of Jesus. He simply states that the proceeds of the sale of the rich young mans' possessions should be given to them. The dense eschatological language of Matthew draws on a number of Jewish eschatological concepts (e.g. the reference to the remade world, the Son of Man on his throne of glory; the twelve disciples sitting on thrones judging the tribes of Israel; the receiving of a hundredfold reward and eternal life).

Matthew also incorporates material unique to him as motivation for obeying his commands. The promises in 19:21 that the young man would have a treasure in heaven and the comment that the rich would struggle to enter into the kingdom of heaven (19:23), for example, both reflect Matthew's unique reference to the kingdom of heaven

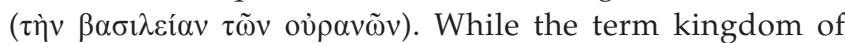
heaven occurs 32 times in Matthew it does not occur in any other New Testament text, or in any preceding Second Temple literature. Matthew also uses different forms of the numen oủpavós 82 times in his Gospel (Pennington 2007:2) - which is more than 30\% of the total use of ovjpavó in the New Testament. No other New Testament writing refers to heaven as often as Matthew (in comparison Rv has 52 references; Mk 18; Lk 35 and Jn 18). ${ }^{18}$ Interestingly the focus of the words of Jesus in Matthew 19:16-29 is on the reward that those who obey his command to renounce their possessions would receive, and not on the punishment that would befall them if they did not obey his words. The latter is, however, the implication of the references to those who are unable to enter the kingdom of heaven (19:23-24) and to the future judgement over the twelve tribes (19:28).

While Matthew often refers to the theme of reward for virtuous conduct (e.g. 5:3-12, 4; 6:2, 5, 16, 19-21, 41-42; 10:41-42; 19:29), it is unclear if some of his followers would receive

16.The interchangeability of "eternal life" and "entry into the kingdom of heaven is marked by the way that 'enter into the life' in Matthew 19:17 is taken up in Matthew 19:23-24 as 'enter into the kingdom of heaven' (Nolland 2005 788-789).

17. While the poor are a prominent theme in Luke (cf. 1:51-53; 4:18; 6:20; 6:24; 7:22; $14: 13-14,16-24 ; 16: 19-31)$, it is noteworthy that Matthew $5: 3$ refers to the poor in spirit, unlike Luke 6:20 which refers to the poor and, contra to Luke 14:13-14, Matthew has no command to invite those who cannot repay one (the poor), or a reference to the poor in the parable of the banquet (cf. Lk 14:21 and Mt 22:10). Matthew 11:5 does, however, mention that the poor had the good news preached
to them as does Luke 7:22.

18.The analysis of Pennington (2007:2) has revealed that 'heaven' is used within a wide semantic range by Matthew and that not all uses by Matthew have a spiritual meaning (e.g. the birds of heaven - Mt 6:26; 8:20; 13:32). 
a greater reward than others. This is also true with regard to the renouncement of possessions. In 10:37-39, Matthew relates an uncompromising call by Jesus to break with all family ties and to follow him, even though it could lead to suffering similar to his, in order to be worthy of him (каì ôs

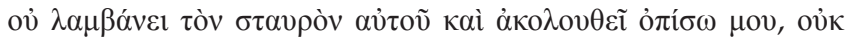

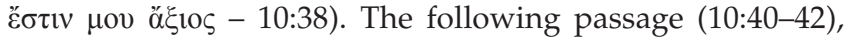
however, addresses those who receive one of the wandering Christian prophets, or one of the little ones, stating that by their simple act of hospitality they would receive the same reward as the prophet. There thus appear to be different tasks - being sent as a prophet and practicing hospitality that would be similarly rewarded. A similar sentiment is articulated in the parable of the Workers in the Vineyard (Mt 20:1-16) since all - those who were hired first, and those who had been hired at the end of the day - received the same payment from the owner thereof. The hope for an eschatological reward by God that was promised by Jesus thus apparently motivated both those who lived settled lives and those who had renounced all their possessions to live according to his teaching.

\section{Conclusion}

This article investigated three related questions. Firstly, it was asked if the renouncement of possessions was a requirement for all who wanted to follow the Matthean Jesus or join the Matthean community. Secondly, it asked whether this requirement lead to a distinction according to Matthew within the pre- and post-Easter followers of Jesus between those who adhered to a stricter ethic of Jesus and those who did not (i.e. between religious virtuosi and non-virtuosi). Finally, the question was asked as to what motivated some followers of Jesus and members of the Matthean community to comply with it.

In terms of the first question it appears as if the renouncement of possessions was, according to Matthew, practiced by at least some of Jesus' pre- and post-Easter followers as a sign of their commitment to him. The willingness to renounce possessions could have functioned as a test of the commitment of new community members as it did in some Jewish groupings in order to separate those who were serious about following Jesus from those just exploring different religious options for becoming a religious virtuoso. There is, however, little evidence for a formal initiation process into the community of Jesus followers in which the process of sharing of possessions is clearly defined in Matthew. There are, however, with regard to the second question hints in Matthew that the pre- and post-Easter followers of Jesus were compromised of both settled and dispossessed groups. In other words that they both had a two tier structure from the perspective of compliance to Jesus' command to permanently renounce their possessions. Some complied wholeheartedly by leaving possessions and family while others lived a settled family life.

The language Matthew uses as motivation for the renouncement of possessions (the final question investigated), and for the care by those who had not renounced theirs, is primarily eschatological in nature. According to the Matthean Jesus, all who had left their families and possessions would be richly rewarded by God at the eschaton. The authority of Jesus is thus far greater than that of an everyday Rabbi, since he possessed the unique authority to promise a range of eschatological blessings to those who accepted his authority and did his bidding. There is in this regard a noteworthy shift in the depiction of Jesus in Matthew 19:16-30 from being addressed as a teacher of the Torah to being described as the eschatological judge over Israel (19:28).

It should, however, be kept in mind that while Matthew often refers to the theme of the incomparable eschatological reward for virtuous conduct (e.g. 5:3-12, 4; 6:2, 5, 16, 19-21, $41-42 ; 10: 41-42 ; 19: 29)$, it is also possible that those who had left all to follow him (10:37-39) would not be rewarded differently than the settled disciples who had extended hospitality to the wandering Christian prophets (10:40-42). It thus appears as if through the grace of God, both the settled and the dispossessed could enter the kingdom of God through the eye of the needle if they supported Jesus and his followers with their possessions.

\section{Acknowledgements Competing interests}

The author declares that he has no financial or personal relationships which may have inappropriately influenced him in writing this article.

\section{References}

Baumgarten, A.l., 1997, The flourishing of Jewish sects in the Maccabean era An interpretation, Brill, Leiden.

Baumgarten, A.I., 2007, 'Josephus on Ancient Jewish groups from a social scientific perspective', in L.H. Feldman (ed.), Studies in Josephus and the varieties of the ancient Judaism, pp. 1-13, Brill, Leiden. http://dx.doi.org/10.1163/ ej.9789004153899.i-312.5

Berger, K., 2003, Identity and experience in the New Testament, Fortress Press, Minneapolis, MN.

Capper, B.J., 2009, 'Jesus, virtuoso Religion, and the community of goods', in B.W. Longenecker \& K.D. Liebengood (eds.), Engaging economics: New testament scenarios and early Christian reception, pp. 60-83, Eerdmans, Grand Rapids, MI.

Carter, W., 1994, Households and disciples: A study of Matthew 19-20, Sheffield Academic Press, Sheffield.

Coser, L.A., 1974, Greedy institutions; Patterns of undivided commitment, Free Press, New York, NY.

Draper, J.A., 1995, 'Wandering radicalism or purposeful activity? Jesus and the sending of messengers in Mark 6:6-56', Neotestamentica 29(2), 183-202.

Draper, J.A., 1998, 'Weber, Theissen, and "Wandering Charismatics" in the Didache', Journal of Early Christian Studies 6(4), 541-576. http://dx.doi.org/10.1353/ earl.1998.0070

Goffman, E., 1961, Asylums; Essays on the social situation of mental patients and other inmates, Anchor Books, Garden City, NY.

Hays, C.M., 2010, Luke's wealth ethics: A study in their coherence and character, Mohr Siebeck, Tübingen.

Hengel, M., 1981, The charismatic leader and his followers, Crossroad, New York, NY. Johnson, L.T., 1981, Sharing possessions: Mandate and symbol of faith, Fortress Press, Philadelphia, PA.

Luz, U., 2001, Matthew 8-20: A commentary, Fortress Press, Minneapolis, MN.

Malina, B.J., 1996, The social world of Jesus and the Gospels, Routledge, New York, NY.

Nel, M.J., 2014, 'The presence of religious virtuosi and non-virtuosi in the Matthean community', Nederduitse Gereformeerde Teologiese Tydskrif 55(3/4), 729-746.

Nolland, J., 2005, The Gospel of Matthew: A commentary on the Greek text, Eerdmans, Grand Rapids, MI. 
Pennington, J.T., 2007, Heaven and earth in the Gospel of Matthew, Brill, Leiden http://dx.doi.org/10.1163/ej.9789004162051.i-399

Regev, E., 2011, 'Were the early Christians sectarians?', Journal of Biblical Literature 130(4), 771-793.

Runesson, A., 2008, 'Rethinking early Jewish - Christian relations: Matthean community history as Pharisaic intragroup conflict', Journal of Biblical Literature 127(1), 95-132.
Silber, I., 1995, Virtuosity, charisma, and social order: A comparative sociological study of Monasticism in Theravada Buddhism and Medieval Catholicism, Cambridge University Press, Cambridge. http://dx.doi.org/10.1017/ CBO9780511520846

Theissen, G., 1978, Sociology of early Palestinian Christianity, Fortress Press, Philadelphia, PA.

Weber, M., 1963, The sociology of religion, Beacon Press, Boston, MA. 